\title{
PENGARUH SISTEM INFORMASI PERPAJAKAN TERHADAP KEPATUHAN WAJIB PAJAK DAN PENERIMAAN PAJAK DI KANTOR PELAYANAN PAJAK BADAN DAN ORANG ASING SATU MENURUT WAJIB PAJAK
}

\author{
Alief Ramdan \\ Institut Ilmu Sosial dan Manajemen STIAMI \\ Arya.nabila0828@gmail.com
}

\begin{abstract}
Abstrak. Penelitian ini bertujuan untuk mengetahui hubungan dan pengaruh sistem informasi perpajakan yang memadai terhadap kepatuhan wajib pajak dan penerimaan pajak. Penelitian ini dilakukan di lingkungan Kantor Pelayanan Pajak Badan dan Orang Asing (KPP Badora) 1, pada Mei 2006 dengan sampel 115 Wajib Pajak Badan yang diambil secara acak dari 910 wajib pajak atau +/- $2 \%$ dari populasi. Instrumen untuk menjaring data sistem informasi perpajakan (Y1) dan kepatuhan wajib pajak (X1) adalah kuesioner model skala likert sedangkan data penerimaan pajak (Y2) adalah data sekunder yang diperoleh langsung dari KPP Badora 1.

Analisis dilakukan secara kuantitatif dengan dua teknik analisis statistika yang akan digunakan dalam penelitian ini, yaitu analisis regresi dan uji perbedaan Mann-Whitney. Teknik analisis regresi digunakan untuk mengetahui dan memprediksi pengaruh sistem informasi perpajakan terhadap kepatuhanwajib pajak dan penerimaan pajak. Sementara uji perbedaan rata-rata Mann-Whitney digunakan untuk mendeteksi apakah terdapat perbedaan antara tingkat penerimaan pajak KPP Badora 1 antara sebelum digunakannya sistem komputerisasi dan setelah digunakannya sistem tersebut. Interpretasi hasil analisis data menggunakan signifikansi $\alpha=5 \%$.

Hasil analisis regresi menunjukkan bahwa terdapat hubungan yang signifikan antara penerapan sistem informasi perpajakan dengan kepatuhan wajib pajak yaitu sebesar 0,653. Sedangkan besar pengaruh dari penerapan sistem informasi perpajakan terhadap kepatuhan wajib pajak adalah sebesar 42,6\%. Persamaan regresi linearnya $\hat{y}=25,231+0,538$ X. Hasil pengujian Mann-Whitney menunjukkan bahwa tidak terdapat perbedaan yang signifikan antara penerimaan pajak sebelum dan sesudah penerapan sistem informasi perpajakan yang berarti bahwa penerapan sistem informasi perpajakan tidak mempengaruhi secara signifikan terhadap penerimaan pajak.
\end{abstract}

Kata Kunci : Sistem Informasi Perpajakan, Kepatuhan Wajin Pajak, Penerimaan Pajak

Abstract. This study aims to determine the relationship and influence of adequate taxation information system on taxpayer compliance and tax revenue. This research was conducted in the Office of Tax Service of Foreign Body and Person (KPP Badora) 1, in May 2006 with sample 115 Taxpayer Agency taken at random from 910 taxpayers or $+/-2 \%$ of the population. Instrument for collecting data of taxation information system (Y1) and taxpayer compliance (X1) is questionnaire of Likert scale model while tax revenue data (Y2) is secondary data obtained directly from KPP Badora 1.

The analysis was done quantitatively with two statistical analysis techniques to be used in this study, namely regression analysis and Mann-Whitney difference test. Regression analysis techniques used to determine and predict the effect of tax information systems on taxpayer compliance and tax revenue. While the mean difference test of Mann-Whitney is used to detect whether there is a difference between the tax revenue level of KPP Badora 1 between before the use of computerized system and after use of the system. Interpretation of data analysis results using significance $\alpha=5 \%$.

Regression analysis results show that there is a significant relationship between the application of tax information systems with taxpayer compliance of 0.653. While the big influence of the application of tax information system on taxpayer compliance is equal to $42.6 \%$. Linear regression equation $\hat{y}=25.231+0.538 X$. Mann-Whitney test results show that there is no significant 
difference between tax revenues before and after the implementation of tax information system which means that the application of tax information system does not affect significantly to tax revenue.

Keywords: Tax Information System, Tax Compliance Compliance, Tax Receipts

\section{PENDAHULUAN}

Pajak merupakan salah satu alat yang penting bagi pemerintah dalam mencapai tujuan ekonomi, politik, dan sosial yang mengandung berbagai sasaran (1) pengalihan sumber dana dari sektor swasta ke sektor pemerintah; (2) pendistribusian beban pemerintah secara adil dalam kelas-kelas penghasilan; dan (3) mendorong pertumbuhan ekonomi, stabilisasi harga, dan perluasan kesempatan kerja (Zain, 2005: 6). Ketika Indonesia merdeka, citra negatif perpajakan di masa kolonial masih melekat kuat dibenak masyarakat. Bahkan oleh sebagian masyarakat, kemerdekaan yang telah diraih dipersepsikan sebagai kebebasan dari eksploitasi, termasuk pajak (belasting) sehingga membuat pemerintah baru dilematis.

Secara psikologis-politis pemerintah sangat kesulitan dalam menjelaskan peranan dan fungsi pajak bagi keberadaan negara dan terwujudnya cita-cita kemerdekaan. Sementara pembangunan yang dimaksudkan untuk merealisasikan harapan itu membutuhkan dana yang berasal dari masyarakat yang tidak sedikit (Harahap: 2004:1). Pengelolaan penerimaan pajak dilakukan melalui instrument kebijakan perpajakan (tax policy) dan administrasi perpajakan (tax administration). Reformasi kebijakan perpajakan (tax policy reform) dimulai 1983 dengan diterbitkannya seperangkat peraturan perundang-undangan di bidang perpajakan menggantikan peninggalan pemerintahan kolonial Belanda.

Menurut Mansury (1996: 21), apabila perkembangan dalam masyarakat telah demikian jauh, sedang undang-undang perpajakan telah tidak dapat dipresentasikan sedemikian rupa menampung perkembangan tersebut, maka dalam keadaan demikian perlu dilakukan reformasi perpajakan lagi.
Perubahan yang dilakukan pada 2000, dengan keluarnya peraturan UU No. 16 Tahun 2000 tentang Perubahan Kedua atas UU No.6 Tahun 1983 tentang Ketentuan Umum dan Tata Cara Perpajakan (KUP); UU No.17 Tahun 2000 tentang Perubahan Ketiga atas UU No.7 Tahun 1983 tentang Pajak Penghasilan; UU No. 18 Tahun 2000 tentang Perubahan Ketiga atas UU No. 8 Tahun 1983 tentang Pajak Pertambahan Nilai dan Pajak Penjualan Atas Barang Mewah; serta UU No. 19 Tahun 2000 tentang Perubahan atas UU No. 19 Tahun 1997 tentang Penagihan Pajak. Perubahan tersebut dilakukan untuk mengantisipasi perubahan ekonomi secara global dan menuju penyempurnaan ketentuan perundang-undangan dengan lebih ditingkatkan kepastian hukum dan keadilan, dan diharapkan lebih meningkatkan kepatuhan dan kesadaran wajib pajak.

Di Indonesia tax ratio masih tergolong rendah, sehingga teridentifikasi masih besar potensi-potensi pajak yang masih belum digali dan dioptimalkan. Rendahnya rasio pajak juga mengindikasikan tingginya potential loss, kebocoran, dan praktek-praktek yang tidak benar lain. Ini juga menunjukkan rumitnya persoalan pajak, terutama yang mengandalkan self-assessment system. Sementara sistem tersebut sangat tergantung dari tingkat kesadaran dan kepatuhan wajib pajak. Rendahnya kesadaran dan kepatuhan wajib pajak tentu terkait dengan citra dan persepsi masyarakat dalam memandang pajak.

Di era reformasi perpajakan, dari 1983 sampai sekarang kepatuhan wajib pajak masih tergolong rendah. Dimana jasa dan pelayanan publik yang diberikan pemerintah dirasakan masih buruk. Bahkan tidak sedikitnya masyarakat yang merasa harus "membeli" sesuatu yang sebenarnya sudah menjadi haknya dan kewajiban pemerintah untuk memenuhi dan melayani. Setiap berhubungan 
dengan pemerintah untuk berbagai urusan dan keperluan, masyarakat harus mengeluarkan sejumlah uang. Demikian juga terhadap danadana publik lain yang dipungut secara resmi tidak jelas pengelolaan dan pertanggungjawaban. Singkat fenomena korupsi dan ekonomi biaya tinggi merupakan realitas yang gampang dijumpai, sehingga masyarakat merasa diperas atau terpaksa jika harus mengeluarkan sejumlah uang bagi negara, termasuk pajak. Kesadaran semacam ini telah mendorong masyarakat untuk menghindari pajak atau tidak patuh terhadap ketentuan yang dianut (Harahap, 2004: 5051).

Perilaku masyarakat terhadap beban pajak yang ditanggung bermacam-macam, bila dilihat dari perspektif psikologis sosial. Sebagaimana yang dikemukakan ahli psikolog sosial Herbert Kelman, bahwa motif orang mendaftarkan diri menjadi wajib pajak dan membayar pajak dapat bermacammacam. Motif pertama orang membayar pajak karena dia takut dihukum, bila menyembunyikan pajak atau tidak membayar pajak. Motif kedua membayar pajak karena didorong rasa senang dan hormat kepada petugas pemerintah, khususnya petugas pajak. Motif ketiga orang membayar pajak karena kesadaran bahwa pajak itu memang berguna untuk dirinya sendiri maupun untuk masyarakat luas. Dari ketiga tingkat kepatuhan tersebut, idealnya wajib pajak sampai pada tingkatan ketiga.

Globalisasi menjadikan dunia tanpa batas, dimana pergerakan informasi dan komunikasi berjalan begitu cepat. Dinamika teknologi informatika yang begitu cepat dewasa ini mengakibatkan semakin jelasnya peranan teknologi sebagai alat bantu bagi manusia, khususnya untuk mempermudah tugas-tugas mengumpulkan, mengolah, menyimpan serta menyajikan kembali informasi-informasi yang dibutuhkan. Di negara maju kualitas administrasi perpajakan merupakan faktor penting yang menentukan tingkat dan kualitas penerimaan pengelolaan pajak. Tentu ditentukan oleh kualitas sumberdaya serta dukungan sarana dan prasarana yang digunakan. Di Indonesia kualitas administrasi pajak masih tergolong rendah mutu dan kehandalan. Indikator sejauh ini prosedur pelaksanaan pelayanan (perpajakan) kepada masyarakat masih belum mengantisipasi kebutuhan pelayanan yang serba cepat, tepat, dan akurat. Menurut Harahap (2004: 54-55) bahwa dukungan teknologi (informasi) menjadikan administrasi pajak yang dikelola menjadi lebih efisien dan efektif.

Sedangkan hasil penelitian yang dilakukan Stephen C. Gara Khondkar E. Karim dan Robert E. Pinsker yang berjudul "The Benefits of XML Implementation for Tax Filing and Compliance" menyatakan penggunaan teknologi akan mengurangi biaya dalam kepatuhan pajak. Dengan begitu akan meningkatkan kepatuhan wajib pajak. Selain melakukan reformasi kebijakan perpajakan, Direktorat Jenderal Pajak (selanjutnya disingkat DJP), sejak 2001 telah menetapkan sasaran yang akan diwujudkan dalam jangka waktu 10 tahun yang dituangkan dalam cetak biru (blue print) DJP. DJP mendirikan kantor pajak WP Besar (large taxpayer office-LTO), yang merupakan cikal bakal kantor pajak yang memiliki administrasi perpajakan modern. Kantor pajak WP besar mengimplementasikan suatu local area network (LAN) yang dilengkapi dengan sistem administrasi perpajakan terpadu (SAPT) berikut email account dan akses ke jaringan internet untuk komunikasi internal maupun eksternal.

Teknologi yang berkembang secara pesat telah mengubah tatanan dan sistem manual menjadi sebuah sistem elektronik yang canggih dan serba cepat. Setiap perilaku tradisional dan konvesional telah berubah warna menjadi teknologi digital melalui sistem komputerisasi. Dunia perbankan yang memberikan sistem layanan on line telah mempercepat proses kerja menjadi lebih cepat dan efektif. Dalam rangka efisiensi dan mengefektifan sistem pembayaran pajak secara nasional mulai juni 2003, sistem MP3 diberlakukan. Kondisi ini memberikan kontribusi yang positif yang dapat menepis persepsi minor yang kadang-kadang muncul, seperti merembesnya uang pajak yang 
seharusnya masuk ke kas negara sebagai akibat praktik-praktik yang tidak sehat $(\mathrm{KKN})$. Sistem yang baik diharapkan membawa dampak kontrol yang baik, sehingga keterlibatan perbankan dalam hal ini mendorong semua pihak menciptakan iklim yang positif dan mengeliminasi pikiranpikiran yang mnyimpang dar prosedur.

Dari uraian di atas sistem informasi perpajakan mempengaruhi kepatuhan wajib pajak dan penerimaan pajak dengan studi kasus pada Kantor Pelayanan Pajak Badora 1. Berikut ini muncul pertanyaan besar, seberapa jauh pengaruh antara sistem informasi perpajakan terhadap kepatuhan wajib pajak dan penerimaan pajak di Kantor Pelayanan Pajak Badan dan Orang Asing (Badora) satu?

\section{TINJAUAN PUSTAKA}

Administrasi dilakukan oleh manusia, siapa mereka, apa motivasinya, untuk melaksanakan dan melanjutkan dalam pelayanan masyarakat. Pemerintah, serikat pekerja, dan partai politik berlomba-lomba untuk mempunyai sifat loyalitas yang tinggi dan melayani sebagai pekerja atau sebagai pegawai pemerintahan. Berdasarkan Filsafat administrasi, dapat diartikan sebagai keseluruhan proses kerja sama antara dua orang manusia atau lebih yang didasarkan atas rasionalitas tertentu untuk mencapai tujuan yang telah ditentukan sebelumnya. Sementara menurut Dimock \& Dimock (1978: 13) administrasi adalah suatu ilmu yang mempelajari apa yang dikehendaki rakyat melalui pemerintah dan cara memperolehnya.

Administrasi atas sumber daya manusia adalah suatu dasar atau pondasi dari administrasi pajak untuk menciptakan kebijakan sumber daya manusia yang konsisten dibutuhkan 3 dasar yang berbeda dari variabel-variabel yang adil, seperti dalam memahami pentingnya suatu hubungan yang dinamis di dalam suatu organisasi. Tiga dasar tersebut adalah (1) peraturan yang kompleks dan lengkap dan pelaksanaan tugas diberikan tahapan-tahapan; (2) kemampuan pribadi yang membutuhkan atau menginginkan untuk melaksanakan pekerjaan dan (3) kompensasi yang berbeda (Birds and Jantscher, 1992: 343-362).

Suatu sistem perpajakan yang baik apabila administrasinya maupun pemenuhan kewajiban perpajakan oleh wajib pajak, dilaksanakan dengan biaya yang sekecil mungkin. Biaya administrasi pajak seharusnya tidak lebih tinggi dalam perbandingan dengan peningkatan penerimaan. Efisiensi dalam perpajakan bukan hanya atas biaya yang dikeluarkan oleh badan pemungut pajak tetapi juga atas biaya yang dikeluarkan oleh pihak pembayar pajak. Oleh karena itu, administrasi pajak yang baik mengadopsi prinsip ketepatan, kecepatan, keadilan, tegas dan lugas. Untuk mencapai prinsip-prinsip tersebut, penggunaan komputer merupakan alat yang paling tepat dalam menunjang pengembangan dan penyempurnaan administrasi pajak. Salah satu tujuan yang obyektif dari administrasi perpajakan adalah menciptakan sistem yang efisien dalam seleksi wajib pajak untuk dilakukan pemeriksaan, dengan terfokus kepada wajib pajak yang melakukan penghindaran pajak (Birds and Jantscher, 1992: 228).

Hakikat misi dari instansi penyelenggaraan pemungutan pajak adalah tanggung jawab untuk menciptakan dan meningkatkan kepatuhan membayar pajak atau kesadaran memenuhi kewajiban pajak merupakan kebutuhan yang nyata. Kegiatan pelaksanaan pemungutan pajak-pajak daerah itu sendiri dilaksanakan sesuai dengan mata rantai pemungutan pajak yaitu pendataan dan pemeriksaan, penetapan dan penagihan pajak. Menurut Pudyatmoko (2002: 57) dalam melaksanakan pemungutan pajak memiliki beberapa cara, yaitu (1) stelsel nyata (riil stelsel) yaitu pengenaan pajak didasarkan pada obyek (penghasilan) yang nyata sehingga pemungutannya baru dapat dilakukan pada akhir tahun pajak; (2) stelsel fiktif (fictive stelsel) yaitu pengenaan pajak didasarkan pada suatu anggapan yang diatur oleh undang-undang, misalnya penghasilan suatu tahun dianggap sama dengan tahun sebelumnya, dan (3) stelsel campuran yaitu 
merupakan kombinasi antara stelsel nyata dan stelsel fiktif, dimana pada awal tahun besarnya pajak dihitung berdasarkan suatu anggapan, kemudian pada akhir tahun besarnya pajak disesuaikan dengan keadaan sebenarnya.

Selain itu pemungutan pajak juga perlu mempertimbangkan berbagai aspek seperti keadilan, kepastian, kemudahan, maupun efisiensi dalam pelaksanaan. Dalam hal ini Adam Smith mengemukakan the four maxims atau the four canons yang kemudian dikenal luas sebagai azas-azas pemungutan pajak, yaitu:

a. Asas Equity, yang berarti bahwa setiap orang yang mempunyai kondisi yang sama harus dikenai pajak yang sama pula. The four maxims pertama ini kemudian menjadi inspirasi bagi asas keadilan dalam pemungutan pajak.

b. Asas Certainty atau azas kepastian. Azas ini menjamin setiap orang untuk tidak ragu-ragu dalam menjalankan kewajibannya membayar pajak karena segala sesuatunya sudah jelas. Maxim kedua ini selajutnya menjadi inspirasi bagi asas yuridis.

c. Asas Convenience of Payment. Asas ini menekankan pentingnya saat dan waktu yang tepat bagi wajib pajak dalam memenuhi kewajiban perpajakannya. Selanjutnya maxim ketiga ini menjadi inspirasi bagi asas ekonomi.

d. Asas Eficiency. Asas ini menekankan pentingnya efisiensi dalam pemungutan pajak, artinya biaya yang dikeluarkan dalam melaksanakan pemungutan pajak tidak boleh lebih besar dari jumlah pajak yang dipungut. Maxim keempat ini kemudian menjadi inspirasi bagi asas financial.

Menurut Mardiasmo (2001: 8) , asas pemungutan pajak ada 3 yaitu:

a. Asas Domosili, yaitu negara berhak mengenakan pajak atas seluruh penghasilan wajib pajak yang bertempat tinggal di wilayahnya, baik penghasilan yang berasal dari dalam maupun dari luar negeri. b. Asas Sumber, yaitu negara berhak mengenakan pajak atas penghasilan yang bersumber atas penghasilan yang bersumber di wilayahnya tanpa memperhatikan tempat tinggal Wajib Pajak.

c. Asas Kebangsaan, yaitu pengenaan pajak dihubungkan dengan kebangsaan suatu negara misalnya pajak bangsa asing di Indonesia dikenakan pada setiap orang yang bukan berkebangsaan Indonesia yang bertempat tinggal di Indonesia. Asas ini berlaku untuk Wajib Pajak Luar Negeri.

Reformasi administrasi perpajakan jangka menegah (3-5 tahun) yang digulirkan Direktorat Jenderal Pajak (DJP) menurut Hadi Purnomo bertujuan untuk (i) meningkatkan kepatuhan wajib pajak, (ii) meningkatkan kepercayaan terhadap administrasi perpajakan dan (iii) meningkatkan produktivitas aparat perpajakan (Subiantoro, 2004: 218). Kepatuhan yang ada dapat berupa secara formal, dimana wajib pajak memenuhi kewajiban perpajakan sesuai ketentuan undang-undang perpajakan dan kepatuhan material dimana wajib pajak secara substantif memenuhi semua ketentuan material perpajakan. Sejak 1983, sistem pemungutan pajak di Indonesia berubah dari official assessment menjadi self-assessment yang diperlukan tindakan pengawasan. Pada dasarnya tujuan utama pemeriksaan untuk menguji tingkat kepatuhan wajib pemenuhan kewajiban perpajakan yang telah dilaksanakan atas dasar sistem selfassessment.

Salah satu faktor juga ikut menentukan tinggi rendahnya kepatuhan adalah besarnya biaya-biaya yang harus dikeluarkan oleh wajib pajak. Sementara itu pemerintah di seluruh dunia pada saat ini menghadapi 'tekanan' dari berbagai pihak untuk meningkatkan kualitas pelayanan publik dan meningkatkan partisipasi aktif dalam menyebabkan e-government atau pemerintahan berbasis elektronik semakin berperan penting bagi semua pengambilan keputusan. Pemerintah Tradisional yang identik dengan paper based administration 
mulai ditinggalkan. Pemerintah dituntut memberikan perhatian dan memanfaatkan sumber dayanya untuk mempersiapkan ketersediaan informasi dan pelayanan secara on-line, yaitu dengan menggunakan teknologi untuk pembangunan ekonomi (Muller, 2002: 33). Secara lebih sederhana e-government merupakan sistem teknologi informasi yang dikembangkan oleh pemerintah dalam memberikan pilihan kepada masyarakat kapan dan dimanapun mereka bisa mendapatkan kemudahan akses informasi dan layanan pemerintah yang diberikan kepadanya. Ditjen Pajak merencanakan mengimplementasikan program modernisasi perpajakan secara komprehensif yang mencakup semua lini operasi organisasi secara nasional.

E-Government bukan sekedar website pemerintahan, melainkan juga peningkatan kualitas layanan publik secara efektif dan efisien. Singkatnya, pemanfaatan teknologi informasi dalam e-government mencakup dua aktifitas yang saling berkaitan. Penerapan egovernment menunjang keberhasilan pencapaian good government (kepemerintahan yang baik) yang pada hakikatnya merupakan suatu konsep tentang penyelenggaraan pemerintahan yang melibatkan banyak pihak (stakeholders) yang secara umum dapat dikategorikan dalam tiga komponen utama yaitu pemerintah, dunia usaha (swasta), dan masyarakat, secara efektif. Di Indonesia praktik ini dilandasi Instruksi Presiden No. 3 Tahun 2003 tentang Kebijakan dan Strategi Nasional Pengembangan e-Government. Sebagai suatu institusi pemerintah, DJP yang bertugas dalam penyelenggaraan pemungutan pajak juga telah mengupayakan implementasi egovernment dalam menjawab tantangan dan perkembangan globalisasi. DJP telah menerapkan Sistem Informasi Perpajakan (SIP) yang disempurnakan lagi menjadi Sistem Informasi - Direktorat Jemderal Pajak (SI-DJP). Penerapan lain dari konsep egovernment dalam organisasi DJP adalah dibuatnya situs pajak DJP yaitu www.pajak.go.id.

Ilmu sistem informasi adalah bagian dari ilmu informatika dan merupakan bagian penting berikutnya daripada ilmu administrasi. Sementara ilmu tata usaha adalah sistem informasi yang berlangsung melalui berbagai macam pekerjaan kertas (paper work) dan diselenggarakan melalui unit-unit organisasi yang disebut kantor. Sehingga ilmu sistem informasi manajemen menjadi sistem tata usaha modern dalam bentuk yang komprehensif, integratif, dan memakai komputer. Sistem informasi manajemen diperlukan justru oleh organisasiorganisasi besar, dimana terdapat kecenderungan-kecenderungan yang paradoksal yaitu kecenderungan ke arah sentralisasi pada tingkat pimpinan di dalam pengambilan keputusan-keputusan guna mencegah desintegrasi atau pengkotakanpengkotakan. Pentingnya sistem informasi manajemen terletak pada penyediaan yang serba cepat, jitu dan lengkap daripada informasi untuk keperluan manajemen.

Dengan semakin berkembangnya keperluan dan hasil informasi pada setiap unit kerja dalam organisasi, maka setiap unit organisasi merupakan suatu subsistem informasi karena itu pada organisasi modern tidak perlu diadakan suatu unit pusat sistem informasi yang lengkap, yang perlu diadakan pengolahan data. Aplikasi-aplikasi pada akuntansi berbeda dengan sistem-sistem transaksi lainnya. Sistem-sistem akuntansi mengelola catatan-catatan dan memproses data yang mengontrol arus aset dan liabilitas perusahaan atau individu lain. Pada sistemsistem akuntansi keakuratan harus sampai sen-senan. Data tunai, penjualan dan kredit tidak boleh keliru. Untuk melindungi keakurasian data, sistem informasi komputer harus memberikan keyakinan sebaik mungkin bahwa data yang dimasukkan adalah benar dan sesudah dimasukkan ke komputer keakurasiannya tetap terpelihara. Sehingga dibutuhkan umpan balik untuk melunakkan dan mengurangi penyimpangan terhadap standar yang disebut umpan balik negatif. Sedangkan umpan balik positif menambahkan kekuatan arah gerak sistem. Jadi umpan balik positif menyebabkan sistem mengulangi atau memperbesar penyesuaian atau kegiatan. 
Hal ini juga yang berlaku di perpajakan. Di Amerika Serikat pelayanan informasi pajak sudah menjangkau wajib pajak sehingga bila ada wajib pajak yang membutuhkan informasi pajak, dapat secara langsung menelpon pusat informasi pajak secara gratis. Di Inggris informasi pajak hampir bisa diperoleh dalam setiap acara pameran. Di Australia, pemerintah menyediakan mobilmobil yang mengantarkan informasi perpajakan secara door to door. Sedangkan di Swedia, informasi pajak disampaikan melalui karikatur yang penuh rasa humor. Sedangkan di Indonesia, informasi pajak masih sulit didapat dan belum ada sistem layanan informasi yang mudah dijangkau wajib pajak. Kadang-kadang brosur yang disebarkan masih sangat terbatas, bahasanya kurang komunikatif, kurang digemari, menggunakan jorgan-jorgan pajak. Keterbatasan inilah yang menjadi salah satu sebab masyarakat wajib pajak kurang mengenal betul arti, keterlibatan, dan urgensi pajak dalam perekonomian Indonesia. Bahkan masyarakat wajib pajak acap kali menghindari pajak atau anti pajak karena pengetahuan pajaknya masih rendah. Hal ini menimbulkan kesadaran membayar pajak yang rendah pula (Yapnindo, 1995: 71-72).

Melalui penggunaan teknologi informasi yang tepat, cepat, murah diharapkan akan mendorong kepatuhan wajib pajak melalui berbagai bentuk pelayanan perpajakan yang handal. Keberadaan teknologi dalam sistem perpajakan modern adalah keniscayaan. Secara konsepsional, dengan memasukkan (input) teknologi ini diyakini efektifitas dan efisiensi pengelolaan pajak akan dapat lebih ditingkatkan. Semakin majunya teknologi, terutama informasi (komputerisasi), maka banyak persoalan dan kendala perpajakan yang dapat dipecahkan. Keniscayaan masukan teknologi juga didukung oleh realitas sosial dimana ada kecenderungan kuat bahwa sebagian besar masyarakat akan menggunakan teknologi sebagai basis pengelolaan usaha dan kegiatan agar efisien, cepat, dan tepat dalam setiap pengambilan keputusan. Ironisnya, administrasi pemerintahan yang bermaksud memberikan pelayanan publik masih banyak yang bersifat manual dan ketinggalan zaman dalam hal teknologi yang menjadi faktor penyebab utama rendahnya kualitas pelayanan pemerintah.

Oleh karena itu peraturan yang ada dari mulai administrasi perpajakan harus disebarluaskan, diumumkan, terutama kepada wajib pajak dengan format yang mudah dimengerti masyarakat, mudah ditemui, mudah dibaca dan sebagainya. Dari sisi dukungan teknologi, administrasi penerimaan pajak masih belum berbasiskan teknologi informasi secara maksimal. Dari segi wajib pajak belum information technology minded, sehingga banyak ditemui berbagai hambatan yang disebabkan oleh masih rendahnya penggunaan teknologi dalam pengelolaan administrasi penerimaan pajak. Dari sisi masyarakat, rendahnya tingkat kepatuhan wajib pajak karena persoalan sistem dan prosedur perpajakan yang masih berbelit/rumit. Sistem administrasi perpajakan yang ideal dalam pelaksanaan sistem pelayanan harus berorientasi pada kebutuhan dan kepuasan masyarakat. Hal ini sejalan dengan konsep sistem self-assessment yang menyandarkan diri pada kesadaran dan kepatuhan wajib pajak. Manfaat internet untuk perpajakan adalah e-mail untuk kepentingan komunikasi cepat, data warehousing, untuk kepentingan penyimpanan data, online registration untuk kepentingan administrasi pendaftaran NPWP lewat internet, e-transaction and e-payment untuk kepentingan transaksi dalam pembayaran pajak secara online, e-consulting, untuk kepentingan konsultasi pajak secara cepat dan mudah, e-SPT untuk kepentingan pemasukan SPT secara online dan realtime, dan e-filing untuk proses penyampaian SPT lewat internet.

\section{METODE PENELITIAN}

Jenis penelitian yang digunakan dalam penelitian ini adalah jenis penelitian dengan pendekatan kuantitatif dan kualitatif, dimana pendekatan kuantitatif yaitu jenis penelitian yang dilakukan terhadap data yang berbentuk 
angka, baik angka yang merupakan representasi dari suatu kuantitas murni maupun angka yang merupakan hasil dari konversi data kualitatif (data kualitatif yang dikuantifikasikan) dan pendekatan kualitatif yaitu jenis penelitian yang dilakukan terhadap data-data non angka seperti, hasil wawancara atau catatan laporan bacaan dari buku-buku, artikel dan juga termasuk non tulisan seperti foto, gambar atau film (Irawan, 2004: 92-94). Metode penelitian dalam penulisan ini menggunakan metode survey dengan tingkat eksplanasi assosiatif dan komparatif yang akan dilihat apakah terdapat hubungan antara penggunaan sistem informasi dengan tingkat kepatuhan wajib pajak.

Sementara lokasi penelitian ini dilaksanakan di wilayah Kantor Pelayanan Pajak Badan dan Orang Asing (Badora) 1 dengan waktu penelitian pada Mei 2006. Populasi dalam penelitian ini adalah seluruh wajib pajak badan yang terdaftar pada KPP Badora 1 dengan jumlah 1752 wajib pajak dan yang merupakan wajib pajak aktif adalah 910. Arikunto dalam Riduwan (2003: 56) menyatakan bahwa sampel adalah bagian dari populasi (sebagian atau wakil populasi yang diteliti). Sampel penelitian adalah sebagian populasi yang diambil sebagai sumber data dan dapat mewakili seluruh populasi. Sehingga karena tidak semua data dan informasi akan diproses dan tidak semua orang atau benda akan diteliti, maka cukup dengan menggunakan sampel yang mewakili. Besar sampel dikatakan representatif atau dapat mewakili populasi apabila jumlah subyeknya besar, dapat diambil antara $10 \%$ sampai $15 \%$. Mengingat jumlah populasi yang menjadi obyek penelitian ini cukup banyak maka sampel yang digunakan 10\% yaitu dari total 910 orang diambil 91 orang, namun pada akhirnya sampel yang diambil 115 orang.

Untuk teknik pengumpulan data dilakukan melalui berbagai sumber untuk memperolah data yang akurat. Teknik tersebut menggunakan sekunder yang oleh Stewart (1984: 11) dijelaskan "secondary information consists of sources of data and other information collected by others and achieved in some from. These sources include government reports, industry studies, and syndicated information services as well a as the traditional books and journals found in library." Pengumpulan data sekunder dilakukan peneliti yaitu dengan studi dokumenter atau studi kepustakaan dengan mempelajari ketentuan peraturan perpajakan, buku-buku, jurnal, artikel dan literatur lain yang membahas tentang sistem informasi perpajakan di Indonesia seperti e-SPT, ePayment, e-Fling, dan sebagainya.

Untuk data primer dengan menggunakan instrumen penelitian berupa angket (kuesioner) serta wawancara tidak terstruktur. Oleh Malhotra (1996: 116), data primer didefinisikan "primery data are originated by a researcher for the specific purpose of addressing the problem at hand." Sedangkan teknik analisis data dengan menggunakan statistik deskriptif dan inferensial. Dalam penelitian ini statistik yang digunakan untuk menganalisis data dengan cara mendeskripsikan atau menggambarkan data yang telah terkumpul sebagaimana adanya tanpa bermaksud membuat kesimpulan yang berlaku untuk umum. Sedangkan statistik inferensial digunakan untuk menentukan jawaban berdasarkan perhitungan statistik.

Selanjutnya dilakukan uji validitas butir kuesioner untuk menunjukkan ukuran yang benar-benar mengukur apa yang akan diukur. Untuk menganalisis butir kuesioner ditentukan dengan menggunakan rumus koefisien korelasi Rank Spaerman dengan rumus sebagai berikut:

$r_{s}=1-\frac{6 \sum d_{i}^{2}}{n(n-1)}$

Adapun uji reliabilitas adalah untuk tingkat keterpercayaan hasil suatu pengukuran. Pengukuran yang memiliki reliabilitas tinggi, yaitu pengukuran yang mampu memberikan hasil ukur yang terpercaya (reliabel). Reliabilitas merupakan salah satu ciri atau karakter utama intrumen pengukuran yang baik. Teknik perhitungan koefisien reliabilitas yang digunakan disini adalah dengan menggunakan Koefisien 
Reliabilitas Alpha yang dihitung dengan menggunakan rumus sebagai berikut :

$\alpha=\frac{k}{k-1}\left(1-\frac{\sum_{i=1}^{k} S_{i}^{2}}{S^{2}{ }_{\text {total }}}\right)$

dimana :

$\mathrm{k}$ adalah banyaknya belahan item

$\mathrm{Si} 2$ adalah varians dari item ke-i

S2 total adalah total varians dari keseluruhan item

Butir kuesioner yang digunakan dalam menentukan reliabilitas item kuesioner ini adalah item instrumen yang sudah valid. Kemudian terdapat dua teknik analisis statistika yang akan digunakan, yaitu analisis regresi dan uji perbedaan Mann-Whitney. Teknik analisis regresi digunakan untuk mengetahui dan memprediksi pengaruh sistem informasi perpajakan terhadap kepatuhan wajib pajak dan penerimaan pajak. Sementara uji perbedaan rata-rata MannWhitney digunakan untuk mendeteksi apakah terdapat perbedaan antara tingkat penerimaan pajak Kantor Pelayanan Pajak Badora 1 antara sebelum digunakann sistem komputerisasi dan setelah digunakannya sistem tersebut.

\section{HASIL DAN PEMBAHASAN}

Pada bagian ini diuraikan hasil penelitian sesuai dengan metode analisis yang digunakan. Data yang digunakan dalam penelitian ini adalah data sekunder dan data hasil kuesioner. Kuesioner yang dibagikan kepada 115 responden terdiri dari 36 pertanyaan untuk dua variabel yaitu variabel penerapan sistem informasi perpajakan dan kepatuhan wajib pajak. Hasil pengolahan data untuk uji validitas terkait variabel penerapan sistem informasi adalah valid. Dimana seluruh data yang diperoleh memiliki koefisien korelasi di atas 0,300 yang menjadi batasan minimal dari uji validitas. Sedangkan hasil uji reliabilitas menggunakan Alpha Cronbach's menunjukkan nilai koefisien Alpha sebesar 0,9758 yang berada di atas 0,700 dan dapat disimpulkan bahwa item-item pertanyaan dari variabel penerapan sistem informasi valid dan reliabel. Untuk variable kepatuhan wajib pajak, hasil uji validitas variabel kepatuhan wajib pajak memiliki nilai korelasi di atas 0,300 yang menjadi batasan minimal dari uji validitas, dan dapat disimpulkan bahwa seluruh item tersebut valid. Sedangkan hasil uji reliabilitas menggunakan Alpha Cronbach's menunjukkan nilai koefisien Alpha sebesar 0,9489 yang berada di atas 0,700 dan dapat disimpulkan bahwa item-item pertanyaan dari variabel kepatuhan wajib pajak valid dan reliabel.

Hasil penelitian mengenai kecenderungan jawaban responden untuk per item pertanyaan dalam kuesioner adalah sebagai berikut:

1. Sebanyak $48,7 \%$ responden menyatakan setuju dan sangat setuju bahwa sistem informasi DJP (e-Reg, e-SPT, e-Payment, e-Filling) telah memenuhi kebutuhan.

2. Sebanyak $50,5 \%$ responden menyatakan setuju dan sangat setuju bahwa sistem informasi DJP (e-Reg, e-SPT, e-Payment, e-Filling) menghasilkan informasi yang dibutuhkan oleh wajib pajak.

3. Sebanyak $49,5 \%$ responden menyatakan setuju dan sangat setuju bahwa sistem informasi DJP (e-Reg, e-SPT, e-Payment, e-Filling) mempermudah pekerjaan wajib pajak.

4. Sebanyak $45,2 \%$ responden menyatakan setuju dan sangat setuju bahwa sistem informasi DJP (e-Reg, e-SPT, e-Payment, e-Filling) membuat pekerjaan menjadi lebih nyaman (convenience).

5. Sebanyak $46,1 \%$ responden menyatakan setuju dan sangat setuju bahwa dengan menggunakan system informasi DJP (eReg, e-SPT, e-Payment, e-Filling) hal-hal yang berhubungan dengan pajak menjadi lebih mudah.

6. Sebanyak $53,1 \%$ responden menyatakan setuju dan sangat setuju bahwa dengan menggunakan sistem informasi DJP (eReg, e-SPT, e-Payment, e-Filling) hal-hal yang berhubungan dengan pajak menjadi lebih cepat.

7. Sebanyak $31,3 \%$ responden menyatakan setuju dan sangat setuju bahwa dengan 
menggunakan sistem informasi DJP (eReg, e-SPT, e-Payment, e-Filling) hal-hal yang berhubungan dengan pajak menjadi lebih akurat.

8. Sebanyak $45,3 \%$ responden menyatakan setuju dan sangat setuju bahwa sistem informasi perpajakan yang baru (e-Reg, e-SPT, e-Payment, e-Filling) mempermudah dalam memahami perpajakan.

9. Sebanyak $50,4 \%$ responden menyatakan setuju dan sangat setuju bahwa dengan adanya e-registrasi dapat memperoleh NPWP tanpa harus melalui calo.

10. Sebanyak $57,4 \%$ responden menyatakan setuju dan sangat setuju bahwa dengan adanya pembayaran pajak melalui bank, tidak perlu membawa uang dengan tunai sehingga membuat lebih nyaman.

11. Sebanyak $47,8 \%$ responden menyatakan setuju dan sangat setuju bahwa data yang terintegrasi dengan sistem informasi DJP hanya bisa diakses oleh orang tertentu.

12. Sebanyak $48,7 \%$ responden menyatakan setuju dan sangat setuju bahwa sistem yang terpasang memiliki sistem keamanan yang akurat.

13. Sebanyak $40 \%$ responden menyatakan setuju dan sangat setuju bahwa data yang terintegrasi dengan sistem informasi DJP hanya diketahui oleh pihak-pihak yang membutuhkan.

14. Sebanyak $46,1 \%$ responden menyatakan setuju dan sangat setuju dengan dilakukan proses pengecekan sistem keamanan secara berkala.

15. Sebanyak $48,7 \%$ responden menyatakan setuju dan sangat setuju bahwa wajib pajak dapat memperoleh informasi dengan mudah menggunakan SI DJP (eReg, e-SPT, e-Payment, e-Filling).

16. Sebanyak $49,6 \%$ responden menyatakan setuju dan sangat setuju bahwa sistem informasi DJP (e-Reg, e-SPT, e-Payment, e-Filling) memberikan informasi dengan akurat.

17. Sebanyak $47,8 \%$ responden menyatakan setuju dan sangat setuju bahwa tingkat kesalahan yang terjadi semakin minimal dengan penggunaan sistem informasi DJP (e-Reg, e-SPT, e-Payment, e-Filling).

18. Sebanyak $47 \%$ responden menyatakan setuju dan sangat setuju bahwa wajib pajak mendapatkan informasi yang dibutuhkan sesuai kebutuhan (fleksibel) menggunakan sistem informasi DJP (eReg, e-SPT, e-Payment, e-Filling).

19. Sebanyak 45,3\% responden menyatakan setuju dan sangat setuju bahwa pembayaran pajak bermanfaat bagi pribadi dan masyarakat.

20. Sebanyak $42,6 \%$ responden menyatakan setuju dan sangat setuju bahwa mereka rela dan ikhlas atas pembayaran pajak yang dilakukan.

21. Sebanyak $45,3 \%$ responden menyatakan setuju dan sangat setuju bahwa dengan membayar pajak tidak merasa negara mencuri uang wajib pajak.

22. Sebanyak $50,4 \%$ responden menyatakan setuju dan sangat setuju bahwa tidak akan terjadi apa-apa jika tidak membayar pajak.

23. Sebanyak $53,1 \%$ responden menyatakan setuju dan sangat setuju bahwa jika mereka tidak membayar pajak dan diketahui oleh fiskus, yakin akan dapat menyelesaikan dengan mudah.

24. Sebanyak $46,9 \%$ responden menyatakan setuju dan sangat setuju bahwa tarif pajak di Indonesia masih terjangkau.

25. Sebanyak $43,5 \%$ responden menyatakan setuju dan sangat setuju bahwa mereka memahami dan mengerti bagaimana mengisi laporan pajak (SPT) dengan baik dan benar.

26. Sebanyak $43,5 \%$ responden menyatakan setuju dan sangat setuju bahwa mereka membayar pajak tepat waktu.

27. Sebanyak $29,6 \%$ responden menyatakan setuju dan sangat setuju bahwa sistem perpajakan yang ada menjunjung tinggi keadilan.

28. Sebanyak $36,5 \%$ responden menyatakan setuju dan sangat setuju bahwa mereka tidak mau memanfaatkan kelemahan petugas untuk membayar pajak secara tidak benar. 
29. Sebanyak $35,6 \%$ responden menyatakan setuju dan sangat setuju bahwa mereka membayar pajak di tempat yang telah ditentukan.

30. Sebanyak $44,3 \%$ responden menyatakan setuju dan sangat setuju bahwa mereka menyadari resiko membayar dengan jumlah yang tidak benar.

31. Sebanyak $48,7 \%$ responden menyatakan setuju dan sangat setuju bahwa mereka menyampaikan laporan tepat waktu.

32. Sebanyak $50,5 \%$ responden menyatakan setuju dan sangat setuju bahwa mereka menyampaikan data keuangan sesuai dengan ketentuan yang berlaku.

33. Sebanyak $50,4 \%$ responden menyatakan setuju dan sangat setuju bahwa penyampaian data-data dengan benar.

34. Sebanyak $43,5 \%$ responden menyatakan setuju dan sangat setuju bahwa rekayasa dalam data pajak menimbulkan resiko besar.
35. Sebanyak $44,7 \%$ responden menyatakan setuju dan sangat setuju bahwa penyimpanan data pajak adalah sesuatu yang penting dalam pengawasan guna pemenuhan kewajiban pajak.

36. Sebanyak $48,7 \%$ responden menyatakan setuju dan sangat setuju bahwa mereka menyajikan data-data pajak yang sebenarnya.

Secara keseluruhan nilai-nilai yang muncul mayoritas termasuk kategori setuju dan sangat setuju dan memahami aturan pajak yang ada di Indonesia.

Adapun hasil analisis regresi yang digunakan dalam penelitian ini bertujuan untuk mengetahui hubungan dan pengaruh dari penerapan sistem informasi perpajakan terhadap kepatuhan wajib pajak di Kantor Pelayanan Pajak Wajib Pajak Badan dan Orang Asing 1. Berikut hasil analisis regresi linier dengan menggunakan software SPSS versi 11,5:

Tabel 4.1.

\begin{tabular}{|c|c|c|c|c|c|c|}
\hline \multicolumn{7}{|c|}{ ANOVA $^{b}$} \\
\hline Model & & $\begin{array}{l}\text { Sum of } \\
\text { Squares }\end{array}$ & df & Mean Square & $\mathrm{F}$ & Sig. \\
\hline 1 & $\begin{array}{l}\text { Regression } \\
\text { Residual } \\
\text { Total }\end{array}$ & $\begin{array}{l}11166.903 \\
15058.627 \\
26225.530\end{array}$ & $\begin{array}{r}1 \\
113 \\
114\end{array}$ & $\begin{array}{r}11166.903 \\
133.262\end{array}$ & 83.796 & $.000^{\mathrm{a}}$ \\
\hline
\end{tabular}

a. Predictors: (Constant), Penerapan Sistim Inf ormasi

b. Dependent Variable: Kepatuhan Wajib Pajak

Tabel Anova di atas menunjukkan signifikansi dari model linier yang digunakan apakah sudah tepat atau belum. Berdasarkan tabel di atas, dapat diketahui bahwa nilai statistik $\mathrm{F}$ yang diperoleh adalah sebesar 83,796 dengan nilai signifikansi sebesar 0,000 . Nilai signifikansi yang diperoleh jauh lebih kecil dari nilai $\alpha$ yang ditentukan yaitu sebesar $0,05(5 \%)$ yang berarti bahwa $\mathrm{H0}$ ditolak. Dengan demikian dapat diambil kesimpulan bahwa model linier yang digunakan sudah tepat. Hal ini menunjukkan bahwa model tersebut dapat digunakan untuk menjelaskan atau menerangkan hubungan dan pengaruh dari penerapan sistem informasi perpajakan terhadap kepatuhan wajib pajak. Adapun besar hubungan dan pengaruh dari penerapan sistem informasi perpajakan terhadap kepatuhan wajib pajak, dapat dilihat pada tabel Model Summary berikut:

Tabel 4.2.

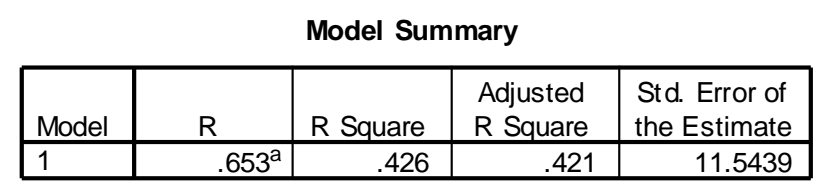

a. Predictors: (Constant), Penerapan Sistim Inf ormasi 
Dari tabel di atas, dapat diketahui bahwa terdapat hubungan antara penerapan sistem informasi perpajakan dengan kepatuhan Wajib Pajak yaitu sebesar 0,653 . Sedangkan besar pengaruh dari penerapan sistem informasi perpajakan terhadap kepatuhan Wajib Pajak adalah sebesar 0,426 atau 42,6\%. Hal ini menunjukkan bahwa penerapan sistem informasi perpajakan dapat memberikan kontribusi sebesar 42,6\% terhadap kepatuhan
Wajib Pajak sedangkan sisanya sebesar $57,4 \%$ merupakan pengaruh dari faktor lain. Karena model regresi linier yang digunakan sudah tepat, maka dilanjutkan dengan uji $\mathrm{t}$ untuk mendapatkan koefisien regresi dan pengujian signifikansinya.

Hasil pengolahan data untuk uji t dengan menggunakan SPSS versi 11.5 dapat dilihat pada tabel berikut ini:

Tabel 4.3.

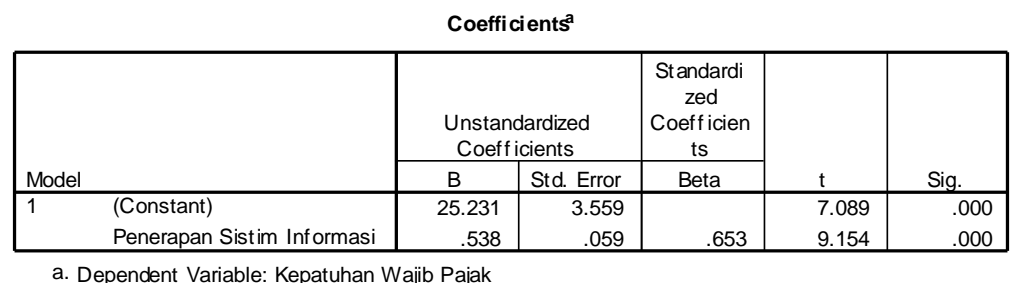

Berdasarkan tabel di atas, dapat diketahui bahwa nilai t-hitung yang diperoleh untuk koefisien regresi penerapan sistem informasi adalah sebesar 9,154 dengan nilai signifikansinya (sig) sebesar 0,000 . Nilai signifikansi yang diperoleh jauh lebih kecil dari nilai $\alpha$ yang ditentukan yaitu sebesar 0,05 . Dengan hasil ini keputusan yang diambil adalah menolak H0 yang berarti bahwa terdapat hubungan dan pengaruh yang signifikan dari penerapan sistem informasi perpajakan terhadap kepatuhan Wajib Pajak. Berdasarkan tabel di atas, persamaan regresi linier yang diperoleh adalah:

$$
\hat{Y}=25,231+0,538 X
$$

Persamaan tersebut dapat diinterpretasikan bahwa konstanta pada model adalah 25,231 memberikan arti bahwa pada saat tidak ada penerapan sistem informasi perpajakan, maka nilai kepatuhan Wajib Pajak sebesar 25,231. Nilai koefisien regresi sebesar 0,538 memberikan arti bahwa penerapan sistem informasi perpajakan mempunyai pengaruh positif terhadap kepatuhan wajib pajak. Nilai tersebut juga memberikan arti bahwa jika penerapan sistem informasi perpajakan naik sebesar satu satuan, maka kepatuhan wajib pajak akan meningkat sebesar 0,538 satuan.

Sementara dari hasil pengujian MannWhitney digunakan dalam penelitian ini bertujuan untuk mengetahui apakah terdapat perbedaan yang signifikan antara penerimaan sebelum dan sesudah penerapan sistem informasi perpajakan di Kantor Pelayanan Pajak Wajib Pajak Besar Badan dan Orang Asing. Berikut ini hasil pengujian dengan menggunakan software SPSS versi 11.5:

Tabel 4.4.

Group Statistics

\begin{tabular}{|ll|r|r|r|r|}
\hline & Group & N & \multicolumn{1}{|c|}{ Mean } & Std. Deviation & Std. Error Mean \\
\hline Penerimaan Pajak & Sebelum & 3 & 377992028241.33 & 514349448966.796 & 296959792818.516 \\
& Sesudah & 1 & 1204517558880.00 & & \\
\hline
\end{tabular}

Berdasarkan tabel Descriptive Statistics di atas, dapat diketahui bahwa rata-rata penerimaan pajak dari 2002 sampai 2004 sebesar Rp. 377.992.028.241,33. Penerimaan pajak yang paling sedikit diperoleh pada 2002 yaitu sebesar Rp. 76.803.414.591,00, sedangkan penerimaan pajak yang paling banyak diperoleh pada 2004 Rp. 971.891.444.340,00 sedangkan penerimaan untuk 2005 sebesar Rp. 1.204.517.558.880,00. 
Tabel 4.5.

\begin{tabular}{|l|c|}
\hline \multicolumn{2}{|c|}{ Test Statistics } \\
\begin{tabular}{|l|r|}
\hline \multicolumn{1}{|c|}{$\begin{array}{c}\text { Penerimaan } \\
\text { Pajak }\end{array}$} \\
\hline Mann-Whitney U & .000 \\
Wilcoxon W & 6.000 \\
Z & -1.342 \\
Asy mp. Sig. (2-tailed) & .180 \\
Exact Sig. [2*(1-tailed Sig.)] & .500 \\
\hline
\end{tabular}
\end{tabular}

Hasil pengujian Mann Whitney dapat dilihat pada tabel Test Statistics di atas. Dari tabel di atas, diketahui bahwa nilai $\mathrm{Z}$ hitung sebesar -1,342 dan nilai signifikansi sebesar 0,180. Dengan tingkat kepercayaan sebesar $95 \%$, maka nilai z tabel sebesar $\pm 1,96$. Oleh karena nilai $\mathrm{z}$ hitung $(-1,342)$ lebih besar dari $\mathrm{z}$ tabel $(-1,96)$ atau nilai signifikansi yang diperoleh lebih besar dari 0,05, maka dapat disimpulkan bahwa H0 diterima yang berarti bahwa penerimaan pajak sesudah dan sebelum penerapan sistem informasi perpajakan adalah tidak berbeda secara signifikan. Hal ini menunjukkan bahwa penerapan sistem informasi perpajakan tidak mempengaruhi secara signifikan terhadap penerimaan pajak di Kantor Pelayanan Pajak Badan dan Orang Asing Satu.

Hasil wawancara secara langsung dapat diketahui bahwa jumlah SPT yang diterima dari tahun ke tahun mengalami penurunan. Berdasarkan hasil tersebut tingkat kepatuhan dari wajib pajak mengalami penurunan. Berdasarkan hasil wawancara dengan petugas KPP Badora I hal ini dikarenakan beberapa hal, yaitu:

a. Banyak wajib pajak badan yang sudah tutup perusahaannya, tetapi untuk menjadi wajib pajak yang dinonaktifkan sampai dengan penghapusan NPWP harus melalui prosedur pemeriksaan yang sulit. Sehingga butuh waktu yang lama. Sedangkan dalam administratif masih aktif.

b. Adanya perbedaan tahun buku pelaporan pajaknya.

c. Adanya penundaan pelaporan SPT

\section{KESIMPULAN DAN SARAN}

Berdasarkan hasil penelitian dan pengolahan data yang dilakukan, maka dapat diambil kesimpulan bahwa hasil uji validitas dan reliabilitas instrumen menunjukkan seluruh item-item pertanyaan untuk kedua variabel sudah valid dan reliabel. Sementara Hasil analisis regresi menunjukkan bahwa terdapat hubungan yang signifikan antara penerapan sistem informasi perpajakan dengan kepatuhan wajib pajak bahwa hubungan tersebut termasuk ke dalam kategori cukup.

Sedangkan persamaan regresi liniernya adalah: $\hat{Y}=25,231+0,538 X$

Hasil pengujian Mann-Whitney menunjukkan bahwa tidak terdapat perbedaan yang signifikan antara penerimaan pajak sebelum dan sesudah penerapan sistem informasi perpajakan.

Bedasarkan kesimpulan bahwa tidak terdapatnya perbedaan yang signifikan antara penerimaan pajak sebelum dan sesudah penerapan sistem informasi perpajakan yang berarti. Bahwa penerapan sistem informasi perpajakan tidak mempengaruhi secara signifikan terhadap penerimaan pajak dikarenakan KPP Badora I menggunakan Sistem Informasi Perpajakan yang baru ini kurang lebih 2 tahun. Akan terlihat lebih jelas apabila dianalisis lebih dari 5 tahun sebelum dan sesudah penggunaan sistem informasi perpajakan.

Adapun saram yang diberikan adalah:

a. Sosialisasi dari penggunaan sistem informasi ini baik itu e-registrasi, e-SPT, perlu ditingkatkan. Sehingga diharapkan semua wajib pajak dapat memahami dan mengerti bagaimana cara penggunaan dan pengoperasian dari sistem informasi tersebut. 
b. Dalam penggunaan sistem informasi ini masih banyak permasalahan yang dihadapi khususnya mengenai programnya itu sendiri. Oleh karena itu diharapkan dari pihak DJP untuk dapat mengatasi sehingga mengurangi permasalahan yang timbul dari kelemahan-kelemahan sistem informasi yang digunakan tersebut.

c. Lebih mengefektifkan kegiatan-kegiatan yang telah ditetapkan, sehingga tujuan dari reformasi administrasi perpajakan dapat tercapai.

\section{DAFTAR PUSTAKA}

$B U K U$ :

Amsyah, Zulkifli. (200). Manajemen Sistem Informasi. Jakarta: PT. SUN.

Atmosudirdjo, Prajudi. (1986). Dasar-dasar Ilmu Administrasi, Cet. Ke-8. Jakarta: Ghalia Indonesia.

Bird, Richard M. dan Milka Casanegra de Jantscher. (1992). Improving Tax Administration Developing Countries. Washington D.C, IMF.

Conover, W.J. (1960). Practical Non Parametric Statistic. John Wiley \& Sons Inc.

Davis, Gordon B. (1999). Sistem Informasi Manajemen. Bagian 1 Pengantar. PBP.

Denzin, Norman K dan Yvonna S. Lincoln (ed). (2000). Handbook of Quality Research. 2nd Ed. California: Sage Publication Inc.

Due, John F. (1985). Keuangan Negara. Terjemahan: Iskandarsyah dan Arief Janin. Jakarta: Universitas Indonesia Press.

Dimock Marshall Edward \& Gladys Ogden Dimock. (1978). Public Adminitration, Terjemahan Husni Thamrin Pane. Jakarta: Aksara Baru.

Fesler, James W. (1990). Public Administration Theory and Practice. Prentice Hall Inc.

Friedenberg, Lisa. Psychological Testing. Allyn and Bacon.

Harahap, Abdul Asri. (2004). Paradigma Baru Perpajakan Indonesia Perspektif
Ekonomi-Politik. Jakarta: Integrita Dinamika Press.

Hatch, Mary Jo. (1997). Organization Theory/ Oxford University.

Jr. Raymond Mcleod. Sistem Informasi Manajemen. Edisi ke-7. Jakarta: PT. Prenhallindo, Prentice Hall International Inc.

Kerlinger, Fred N. (2004). Asas-Asas Penelitian Behavioral, Yogyakarta: Gajah Mada Press.

Malhotra, Naresh K.. (1996). Marketing Research, an Applied Orientation. 2nd Edition. New Jersey Prentice Hall Inc.

Mardiasmo. (2001). Perpajakan. Edisi 9, Cetakan 1. Yogyakarta: Andi.

Martini Huseini. Teori Organisasi (Suatu Pendekatan Makro). Jakarta: Pusat Antar Universitas Ilmu-Ilmu Sosial UI.

Mikesell. (1982). Fiscal Administration, Analysis and Application for the Public Sector. USA: The Dorsey Press.

Musgrave, Richard A. dan Peggy B Musgrave. (2000). Keuangan Negara dalam Teori dan Praktek. Jakata: Erlangga.

Needenhall, William. (1986). Mathematical Statistics with Applications. Third Edition. Boston: Duxbury Press.

Nigthingale, Kath. (2000). Taxation: Theory and Practice. $3^{\text {rd }}$ Edition. UK: Prentice Hall.

Nurmantu, Safri. (2004). Pengantar Perpajakan. Jakarta: Granit.

(1994). Dasar-dasar

Perpajakan. Edisi 1, Cetakan 1. Jakarta: IND Hill-Co.

Perry, Guillermo, dan John Walley. (2000). 'Introduction' dalam Guillmo Perry, John Walley dan Garry McMahon Peny., Fiscal Reform and Structural Change in Developing Countries. Vol. 1. London: MacMillan.

R. Mansury. (1996). PPh Lanjutan, Jakarta: IND.HILL-Co.

Jakarta: YP4.

(1999). Kebijakan Fiskal. -------. (2002). PPh Lanjutan Pasca Reformasi 2000. Jakarta: YP4. 
-------------. (2003). Perpajakan Atas Penghasilan dari Trasaksi Khusus. Jakarta: YP4.

Riduwan, M. (2003). Skala Pengukuran Variabel-variabel Penelitian, Bandung: Alphabeta.

Santoso, Singgih. (2004). Statistik Non Parametrik, Jakarta: Gramedia.

Scott, George M. (1995). Prinsip-Prinsip Sistem Informasi Perpajakan. Jakarta: PT. Raja Grafindo Persada.

Siagian, Sondang P. (1979). Sistem Informasi untuk Pengambilan Keputusan. Jakarta: PT. Gunung Agung.

(2004). Filsafat Administrasi. Edisi revisi. Jakarta: Bumi Aksara.

Slamet, Soelarno. (1999). Pajak Daerah dan Retribusi Daerah. Jakarta: STIA - LAN.

Slemrod, Joel. (1992). Why People Pay Taxes, Tax Compliance and Enforcement. The University of Michigan Press.

Soekanto, Soerjono. (1982). Kesadaran Hukum dan Kepatuhan Hukum. Jakarta: CV Rajawali.

Soemitro, Rochmat. (1987). Asas dan Dasar Perpajakan. Bandung: Eresco.

Steward, David W. (1984). Secondary Research, Information Sources and Methods. Newsburry Park: Sage Publications.

Suandy, Erly. (2001). Perencanaan Pajak. Jakarta: Salemba Empat.

Subiantoro, Heru \& Singgih Riphat. (2004). Kebijakan Fiskal. Jakarta: Kompas.

Sudjana. (1992). Metode Statistika. Bandung: Tarsito.

---------. (1996). Teknik Analisis Regresi dan Korelasi Bagi Para Peneliti. Bandung: Tarsito.

Sugandha, Daab. (1991). Adminitrasi : Strategi, Taktik dan Teknik Penciptaan Efisiensi. Jakarta: Intermedia.

Suparmoko. (1991). Metode Penelitian Praktis untuk Ilmu-Ilmu Sosial dan Ekonomi. Edisi Ke-3. Yogyakarta: BPFE.

Yayasan Produsen Nasional Indonesia (Yapnindo). (1995). Reformasi Perpajakan Indonesia. Cetakan ke-1. Jakarta
Yudkin, Leon. (1971). a Legal Structure for Effective Income Tax Administration. Cambridge.

Zain, Muhammad. (2005). Manajemen Perpajakan. Jakarta: Salemba Empat.

\section{ARTIKEL:}

Gara, Stephen C. and Khondkar E. Karim, and Robert E. Pinsker (2005). The Benefits of XML Implementation for Tax Filing and Compliance. The CPA Journal.

Hutagaol, John. (2005). LTO Tonggak Modernisasi Administrasi Kantor Pajak Indonesia. Jurnal Pajak. Volume 4, No.8, Mei.

Indonesian Tax Review. (2004). Edisi 5.

(2004). Patuhnya

Wajib Pajak Patuh. Volume III, Edisi 9. .-. (2004). Edisi 18.

Edisi 29.

Jurnal Perpajakan Indonesia. (2003). Volume 2, No.12, Juli.

Rachmany Hasan. (2003). Monitoring Pelaporan Pembayaran Pajak (MP3). Jurnal Perpajakan Indonesia, Volume 2, No.12, Juli.

Sagala, Muller. (2002). Membangun Strategi E-Government yang Sukses. Berita Pajak, No. 1468, Tahun XXXIV, 1 Juni.

Salomo Roy V. (2002). E-Government: Suatu Inovasi dalam Kerangka Good Government. Jurnal Bisnis \& Birokrasi, No.2, Vol. X, Mei.

Witte, Ann D. (1985). The Effect of Tax Laws and Tax Administration on Tax Compliance: The Case of The U.S. Individual Income Tax. National Tax Journal.

WEBSITE:

Budi Rahardjo. (2001). Membangun eGovernment,PPAU Mikroelectronika ITB. Www.budi.insan.co.id/articles/egov-makassar.doc.

Didi Marzuki. Apa Itu e-Government. www.iptek.net.id/ind/?ch=ingov\&id=334 http://klikpajak.com/artikel/artikel.php?artikel _id=5646. (2005). Мепији Good 
Governance Melalui Modernisasi Pajak. 23 Mei.

http://tacoen.smedia.ot.id/archieves/2006/03/1 0/penerapane-governance. (10 Maret 2006). Penerapan E-Government.

Julio Adisantoso. (2005). Metode Pengamanan Jaringan Model Kerja eGovernment. $\quad$ www.ipb.ac.id/ipbbhm,/unit/publikasi/file_8_unsri2003.doc

Setiadi, Wigrantoro Roes. (17 Desember 2004). Faktor Sukses Implementasi EGovernment. www.gipi.or.id.

Windrarti Siallagan. (2006). e-Government: Menuju Pelayanan Publik yang Lebih Baik.

www.perbendaharaan.go.id/modul/pustak a/index.php?id=21.

www.ebizzasia.com/0212.2003/itc.0212.01.ht m. (November 2003). Strategi Penciptaan Single Identity Number.

www.goechi.com. (17 Desember 2004). EGovernment Indonesia.

www.itjen.depkeu.go.id/e-registration.asp.

Peran e-Registration, e-SPT, e-Filing dan e-Payment dalam Meningkatkan Kepatuhan Wajib Pajak.

www.warta-egov.com. (14 Desember 2004).

E-Government : Antara Konsep,

Tantangan dan Harapan.

www.wartaekonomi.com/egov/detail.asp?aid $=60348 \& \mathrm{cid}=27$. (6 April 2006). EGovernment, Single Identity Number, Satu Nomor Untuk Semua.

TESIS:

Alam, Sahrul. (2003). Pengaruh Tingkat Pengetahuan Fiskus Terhadap Kepatuhan Wajib Pajak Orang Pribadi Memenuhi Kewajiban Perpajakan.

Apriyanto, Anggun. (2001). Penyebab Ketidakpatuhan Wajib Pajak dan Hambatan Fiskus dalam Pengawasan Pembayaran Masa Pajak Penghasilan Badan (Studi Kasus KPP Jakarta Kebon Jeruk).

Ismail. Aplikasi e-Government dalam Perpajakan di Indonesia, Tinjauan atas Implementasi Monitoring Pelaporan Pajak (MP3).
Sagita, Deaiana Roesli. (2005). Penyampaian SPT Masa Pajak Pertambahan Nilai dan Pajak Penjualan ditinjau dari Prinsip Kemudahan Administrasi Pajak.

Santoso, Iman. (2003). Analisis Peran Sistem Informasi Perpajakan dalam Pemeriksaan (Kantor Pelayanan Pajak Gambir Satu).

Sofyan, Marcus Taufan. (2005). Pengaruh Penerapan Sistem Administrasi Perpajakan Modern terhadap Kepatuhan Wajib Pajak pada Kantor Pelayanan Pajak Wajib Pajak Besar. 